\title{
KHALET AL-JAM'A. A BRONZE AND IRON AGES NECROPOLIS NEAR BETHLEHEM (PALESTINE): RESULTS OF THE 2019 ARCHAEOLOGICAL EXCAVATIONS
}

\author{
Lorenzo Nigro - Daria Montanari - Gaia Cecconi - Sapienza University of Rome \\ Mohammed Ghayyada - Jehad Yasine - Ministry of Tourism and Antiquities - \\ Department of Archaeology and Cultural Heritage
}

\begin{abstract}
In Spring 2019 the Italian-Palestinian joint team of Sapienza University of Rome and the Ministry of Tourism and Antiquities of Palestine Dept. of Archaeology and Cultural Heritage resumed rescue excavations at the Necropolis of Khalet al-Jam'a, $2.2 \mathrm{Km}$ south-east from the Church of Nativity in Bethlehem. Works were focused on Tomb A7, identified in 2015, a huge underground burial place, dating back to the Iron IIC $\left(8^{\text {th }}-7^{\text {th }}\right.$ century $\left.B C\right)$, but also including earlier depositions dating from the $E B I V B-M B$. This suggests that an original EBIV tomb was modified and re-used in the following Middle Bronze and Iron Age. A provisional report of activities and finds is offered below.
\end{abstract}

Keywords: Bethlehem; necropolis; Early Bronze Age IV; Middle Bronze Age; Iron Age II

\section{INTRODUCTION}

In April 2019, the joint team of the Palestinian MOTA-DACH and Sapienza University of Rome ${ }^{1}$ resumed archaeological activities at the Necropolis of Khalet al-Jam'a, $2.2 \mathrm{Km}$ south-east from the center of Bethlehem. ${ }^{2}$ Aim of this season was the excavation of Tomb A7, in the south-western sector of Area A (fig. 1), already recognized and surveyed in 2015, when its entrance was first identified.

\section{TOMB A7}

Tomb A7 is quite different from the majority of the tombs in the KJ necropolis. It is a huge underground complex with at least seven entrances/shafts and ten large chambers with several recesses connected by passages and arches.

The first investigated entrance of Tomb A7 consists of an irregular oval shaft (Shaft 1; fig. 2), of about $0.80 / 0.90 \mathrm{~m}$ of diameter, $1.60 \mathrm{~m}$ deep. The tomb is composed of two sectors (fig. 3), northern (Sector A) and western (Sector B), and Shaft 1 leads to the last one. Sector A, with south-north orientation, counts three chambers joined together (Chambers 1, 9 and 8), and two other attached chambers to the north (Chambers 10 and 6). The second sector, $\mathrm{B}$, is provided with a series of 5 smaller chambers: in order from Shaft 1 to the north, Chambers 2 and 4 (which opens just onto Chamber 2), 3, 5 and 7.

In addition to Shaft 1, six other shafts were found in Tomb A7. One in Chamber 1 (Shaft 2), three in Chamber 9 (Shafts 3, 4 and 5), at short distance one from each other, and another one (Shaft 6) in Chamber 6. Another shaft that runs down (Shaft 8) has been

\footnotetext{
1 The team was composed as follows. MOTA DATCH: Dr. Mohammed Ghayyada, responsible for the Bethlehem district and Mr. Jaber Ahmed er-Joub, archaeologist. University of Rome La Sapienza: Dr. Gaia Cecconi, field responsible; Mr. Lorenzo Indino, archaeologist and photographer; Ms. Cecilia Ripamonti, draftperson; Ms. Cristiana Liberati, draftperson.

2 See Nigro 2015; Nigro et al. 2015; 2017.

Nigro et al. 2015, 190, fig. 20.

ISSN 0393-0300

e-ISSN 2532-5159

Rivista Open Access
} 
identified inside a small niche in Chamber 8, while a circular pit, aside the western wall of the same chamber indicates the presence of another shaft. ${ }^{4}$ All of these shafts were sealed by the same layer of sandy brown soil and limestone chops. In Sector B, the presence of a further shaft is suggested by a cone of earth created by the collapse of the filling from the pit, but it has not been excavated yet (Shaft 7).

Chambers in Sector A have a round or oval shape with several recesses and niches carved along the walls and filled up by earth and stones of large dimensions.

Chambers in Sector B, where the excavation was concentrated during this season, are characterized by an elongated oval shape without niches or subsidiary installations, except for Chamber 2 (fig. 4). The latter one shows a more complex structure, with a height between 1.60 and $1.80 \mathrm{~m}$. Immediately to the right of Shaft 1, there is a platform (Platform 18) carved in the calcareous rock, $2.34 \mathrm{~m}$ wide, flanked by a long channel (Channel 17), $1.50 \mathrm{~m}$ length and $13 \mathrm{~cm}$ wide, and a large niche, $1.05 \mathrm{~cm}$ wide, is on the southern wall, with some stones inside it (Niche 1; fig. 5). The interpretation of this installation needs further investigation.

Layers in Chamber 2 consist of an upper stratum of collapse of brown soft soil with big stones and just a few pottery fragments (Filling 3). Underneath, there is a layer of compact limestone (Filling 9), made by smashed chops collapsed from ceilings, and covering a third layer of compacted brown sandy earth, with limestone fragments and many pottery sherds (Filling 10), laying directly over the bedrock.

The other chambers of Sector B are filled up with big stones and, underneath, a layer of compacted brown sandy earth similar to Filling 10 of Chamber 2 (named Filling 11 in Chamber 3; Filling 12 in Chamber 4; Filling 13 in Chamber 5 and Filling 14 in Chamber 7). Pottery was collected only in the southern half of Chamber 3 , in Chamber 4 (see below $\S$ 2.1.) and between Chamber 5 and 7.

According to the ceramic repertoire, Tomb A7 was firstly used during the Early Bronze Age IVB, and then re-excavated and re-used during the Iron Age IIB-C, as already observed in other tombs of the same necropolis (for example Tomb A1), ${ }^{5}$ in the cemetery of Jebel Daher in Bethlehem, ${ }^{6}$ or in the necropolis of Tell en-Nasbeh (for example Tombs 32, 54 and 5).

\subsection{Pottery from Tomb A7}

The main concentration of pottery was in Chamber 2, in the southern half of Chamber 3 and in Chamber 4, while just a few fragments have been found between Chambers 5 and 7 , over Burial 15a+b (fig. 2; see below $\S 2.4$.). The ceramic repertoire consists of a few complete vessels, basically lamps, and a single cylindrical juglets of MB III. The rest of the ceramic inventory was found in fragmentary preservation state, in an Iron Age IIB-C layer of use disturbed by looters.

Already recognized in 2015, see Nigro et al. 2015, fig. 21, above on the right

Nigro et al. 2015, 185.

Nigro et al. 2017, 16-19.

Mc-Cown - Wampler 1947, 77-84. 


\subsubsection{Pottery: Classes}

The Iron Age repertoire includes the following classes: Simple Ware, Red Slip, Cooking Ware and Storage Ware. Out of 620 fragments from the pottery found in Chambers 2, 3 and 4, 31.93\% belong to Specialized Production (MNV ${ }^{8} 69$ vessels), ${ }^{9}$ 44.99\% Simple Ware (MNV 82 vessels and 24 lamps); 1.78\% Cooking Ware (MNV 3 pots) and $21.30 \%$ Storage Ware (MNV 25 jars).

Pottery found in between Chambers 5 and 7 is distributed as follows: $21.22 \%$ Specialized Production (MNV 7 vessels) ${ }^{10} 60.6 \%$ Simple Ware (MNV 8 vessels and 2 lamps); $18.18 \%$ Storage Ware (MNV 4 vessels).

\subsubsection{Pottery: Classes}

Most frequent vases belong to specialized productions: Red Slip carinated bowls ${ }^{11}$ and hemispherical bowls, ${ }^{12}$ deep bowls, ${ }^{13}$ and kraters (fig. 6), ${ }^{14}$.

Simple Ware enumerates plain bowls, carinated bowls, kraters (fig. 6), ${ }^{15}$ jug and juglets ${ }^{16}$ sometimes with a cross incised on the handle. ${ }^{17}$ Among Cooking Ware, pots ${ }^{18}$ (fig. 7) show an everted grooved or an out-turned rounded rim, with two ribbon handles, sometimes with a cross incised above them. ${ }^{19}$ Moreover, also Storage Ware jars, the socalled hole-mouth pithoi ${ }^{20}$ and hole-mouth jars (fig. 7) ${ }^{21}$ typical of IA IIB-C, were found. Two Storage Ware lids' pommels were also found ${ }^{22}$ (fig. 7).

Furthermore, some stamped handles ${ }^{23}$ were collected: two 2-winged $l m l k$ specimens ${ }^{24}$ of 0 II Type, and one ${ }^{25}$ of X II Type (fig. 8). X II Type represents a diagnostic mark of $7^{\text {th }}$

Minimum Number of Vessel (Rice 1987, 292-293; Voss - Allen 2010).

$25.52 \%$ Red Slip Ware (MNV 39 vessels) and $1.13 \%$ Simple Painted Ware.

9.09\% Red Slip Ware (MNV 3 vessels).

KJ.19.TA7.11/10

KJ.19.TA7.8/11.

3 They exhibit mainly an everted, cut and down-folded or outward-folded rims, as in typologies 4, 6 and 8 of De Groot - Bernick-Greenberg's classification (De Groot - Bernick-Greenberg 2012, 58-62). Sometimes the Red Slip is applied in a concentric circles pattern.

14 KJ.19.TA7.3/43 and KJ.19.TA7.7/9. Kraters are characterized by a thick profiled rim and a high rounded carination (Gitin 2015, 347). KJ.19.TA7.7/9, Red Slip krater with black painted decoration cf.: Beer-Sheba (Singer-Avitz 2016, 593, fig. 12.35:8).

15 KJ.19.TA7.3/33 (fig. 7).

16 KJ.19.TA7.11/64 and KJ.19.TA7.11/69. They are characterized by simple or everted rounded rim, flaring neck and handle extended from the rim to the shoulder (Gitin 2015, 349-350).

17 KJ.19.TA7.11/155. Some of them have also a punctuation at the center of the cross. This feature is already attested in Jerusalem/al-Quds (De Groot - Bernick-Greenberg 2012, fig. 4.30:2-3, 6) and Tel Moza/Qalunya (Brandl - Greenhut - Vainstub 2009, fig. 5.7).

18 KJ.19.TA7.4/15.

19 Gitin 2015, 347-348.

20 KJ.19.TA7.8/55. Sometimes this kind of vessels is defined "jar-krater" (Gitin 2015, 348, pl. 3.3.4:3-5). It found comparisons at Jerusalem/al-Quds (Gitin 2015, 351), Beer-Sheba (Singer-Avitz 2016, 619-620) and Tel Moza/Qalunya (Greenhut - de Groot 2009).

21 KJ.19.TA7.11/118. They are characterized by a plain rim, perpendicular to the wall (Freud 2016, 262), as also at Lachish (Gitin 2015, 349, pl. 3.3.5:10), Jerusalem/al-Quds (De Groot - Bernick-Greenberg 2012) and Tel Moza/Qalunya (Greenhut - de Groot 2009).

22 KJ.19.TA7.10/138

23 Lemaire 1981; Lipschits - Sergi - Koch 2010; 2011; Sergi 2016.

24 KJ.19.TA7.8/42 and KJ.19.TA7.11/103. 
century, that appears in hill-country sites not destroyed in the $701 \mathrm{BC}$ Assyrian campaign. ${ }^{26}$ Parallels have been found at Ramat Rahel, ${ }^{27}$ Gibeon/el- $\mathrm{Jib}^{28}$ or in the same area of Bethlehem, on the slope north of the Basilica of the Nativity. ${ }^{29}$ Other two handles shows two Concentric Circles Type impression with a central dot $^{30}$ (fig. 8). Concentric Circles Type mainly spreads over Highland sites after the end of $8^{\text {th }}$ century, ${ }^{31}$ as Ramat Rahel, ${ }^{32}$ Jerusalem/al-Quds ${ }^{33}$ and Tel Moza/Qalunya. ${ }^{34}$

\subsection{Objects and other finds from Tomb A7}

Objects are distributed in Tomb A7 over the same area of the pottery. A pillar figurine ${ }^{35}$ (fig. 9), depicting a female torso missing head and arms, belonging to Kletter's Type B ("mold-made face JPF") 36 or Type A3c of Gilbert-Peretz's classification ("pillar torso, broken hands"), ${ }^{37}$ was found in Filling 11. This type of figurine is widely spread between the $8^{\text {th }}$ and early $6^{\text {th }}$ century BC ${ }^{38}$ in Central-Southern Levant, ${ }^{39}$ e.g. in Jerusalem/al-Quds, ${ }^{40}$ Tell Beit Mirsim, ${ }^{41}$ Gibeah/Tell el-Fûl, ${ }^{42}$ Tell en-Nașbeh, ${ }^{43}$ Tel Moza/Qalunya. ${ }^{44}$ Such kind of figurines is usually interpreted as votive objects for official or domestic cult of fertility, perhaps as representations of the goddess Asherah ${ }^{45}$ or Astarte. ${ }^{46}$ According to some scholars they could be toys, ${ }^{47}$ or women representations, linked with some sympathetic magic properties. ${ }^{48}$

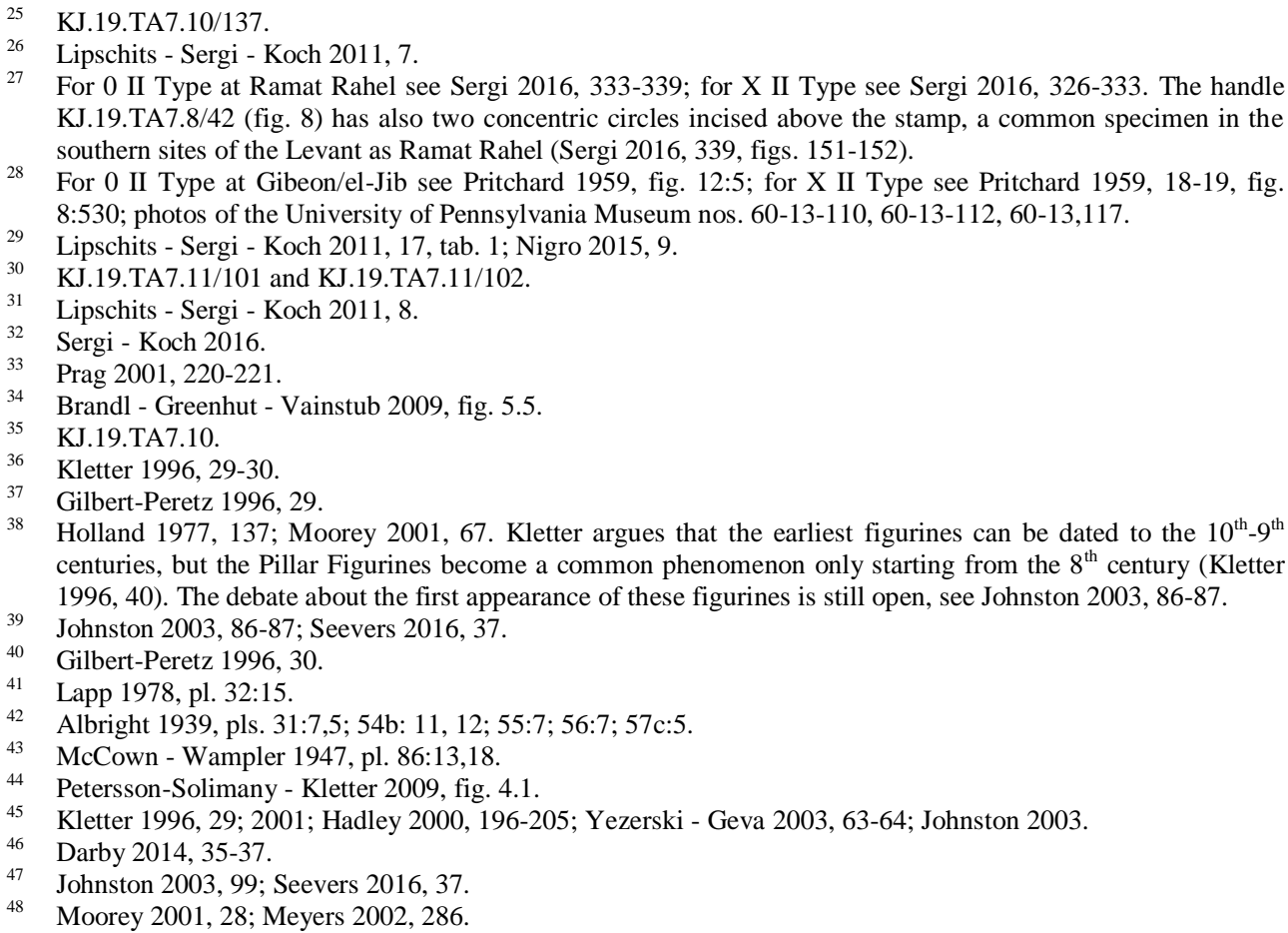

Holland 1977, 137; Moorey 2001, 67. Kletter argues that the earliest figurines can be dated to the $10^{\text {th }}-9^{\text {th }}$ centuries, but the Pillar Figurines become a common phenomenon only starting from the $8^{\text {th }}$ century (Kletter 1996, 40). The debate about the first appearance of these figurines is still open, see Johnston 2003, 86-87. 
Three handmade zoomorphic figurines, one head of an equid, and two bodies of equid were found between Chambers 2 and 3, in Fillings 10 and 11. The head ${ }^{49}$ (fig. 9), almost complete, preserves applied eyes and a cylindrical nose with a punctuation at the end. It is a popular typology in the Levant, sometimes with pierced muzzle to libate, ${ }^{50}$ and found comparisons at Jerusalem/al-Quds, ${ }^{51}$ Tel Moza/Qalunya, ${ }^{52}$ Samaria, ${ }^{53}$ and Beer-Sheba. ${ }^{54}$ The two bodies are preserved in the chest and part of the neck. ${ }^{55}$ Equid figurines are common in southern sites of the Levant during the $8^{\text {th }}-7^{\text {th }}$ centuries, as other zoomorphic figurines (sheep, horned animals, birds) and clay models of tables and chairs. They are sometimes interpreted as votive offerings or toys. ${ }^{56}$

Moreover, several flint cores, three fragments of stone vessels ${ }^{57}$, five stoppers ${ }^{58}$, six pestles, ${ }^{59}$ one grinding stones ${ }^{60}$ were found just inside Chambers 2 and 3, in Fillings 10 and 11, and three marābit faras for tying animals (fig. 10) ${ }^{61}$ inside Chamber 2, in Filling 3.

\subsection{Faunal remains}

Faunal remains from Tomb A7 were hand-collected and analyzed during the excavation. Most of the bones have been found in Chamber $2\left(59.64 \%\right.$ of NISP $\left.{ }^{62}\right)$. However, some samples were collected also in Chambers 3, 5, and 7 (tab. 1). In Tomb A7, the most represented animals are sheep and goats (Ovis vel capra, 11.40\%, and Capra hircus, 3.50\%), followed by donkeys (Equus asinus, 8.77\%), equids (Equidae, 4.39\%), cattle (Bos taurus, 4.39\%), birds (Aves, 1.75\%) and a few pigs (Sus scrofa, $1.75 \%$ ). Medium mammals represents $44.74 \%$, large mammals $22.80 \%$ and indeterminate $32.46 \%$ of total.

In Chamber 2, a high concentration of mammals of medium size, including sheep, one goat, represented by four fragments of horn, and a very small percentage of pigs were

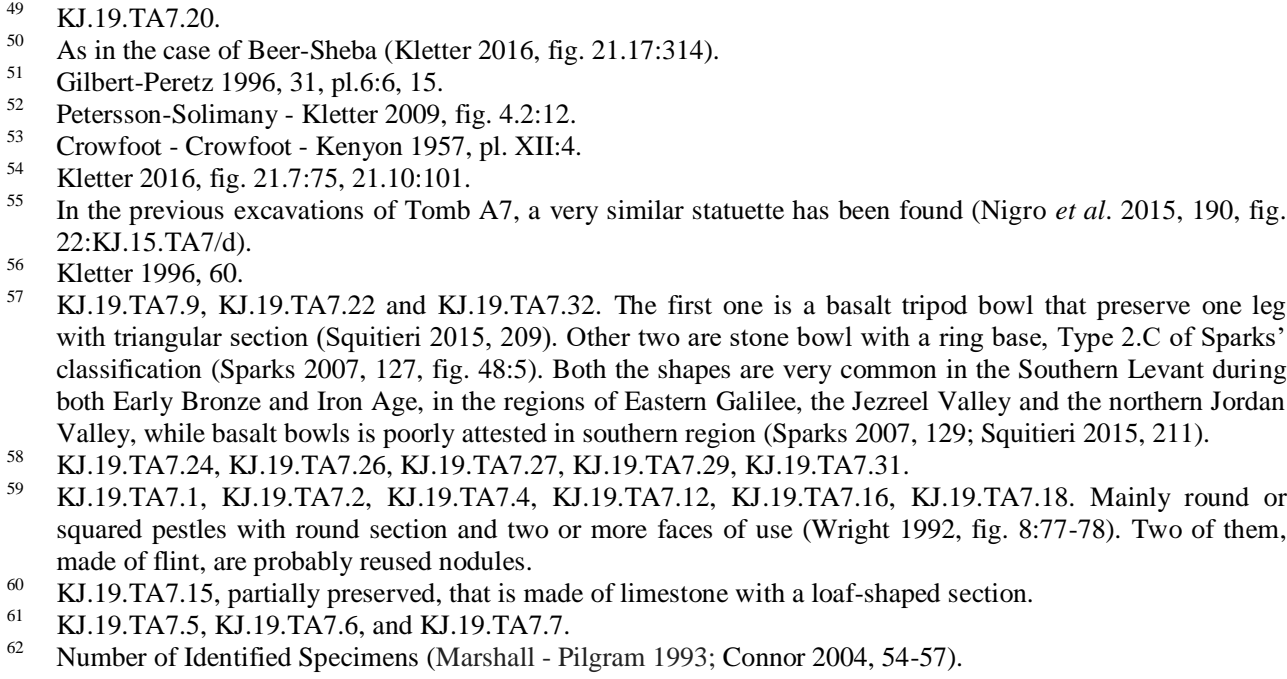

59 KJ.19.TA7.1, KJ.19.TA7.2, KJ.19.TA7.4, KJ.19.TA7.12, KJ.19.TA7.16, KJ.19.TA7.18. Mainly round or squared pestles with round section and two or more faces of use (Wright 1992, fig. 8:77-78). Two of them, made of flint, are probably reused nodules.

60 KJ.19.TA7.15, partially preserved, that is made of limestone with a loaf-shaped section.

$61 \quad$ KJ.19.TA7.5, KJ.19.TA7.6, and KJ.19.TA7.7.

62 Number of Identified Specimens (Marshall - Pilgram 1993; Connor 2004, 54-57). 
found. ${ }^{63}$ Mandibulae with teeth and fragments of long bones are the most numerous among ovine remains. Retrieved bones and especially teeth and mandibulae suggest the presence at least of to two juvenile individuals of sheep/goat.

In Chamber 3, mostly mammals of large size (cattle and donkey) were found, in particular ten donkey's teeth from the same individual. ${ }^{64}$

In conclusion, faunal remains from Tomb A7 follow the general trends of the southern sites of the Levant, ${ }^{65}$ where the ovine is the most spread animal species, both for wool $/ \mathrm{milk}$ production and meat consumption, followed by cattle, and a very small percentage of pigs and birds.

\begin{tabular}{|c|c|c|c|c|c|c|c|c|}
\hline & \multirow{2}{*}{\multicolumn{2}{|c|}{$\begin{array}{l}\text { Chamber 2 } \\
\text { KJ.19.TA7.2.FR1; } \\
\text { KJ.19.TA7.2.FR.2; } \\
\text { KJ.19.TA7.2.FR.4 }\end{array}$}} & \multirow{2}{*}{\multicolumn{2}{|c|}{$\begin{array}{l}\text { Chamber 3 } \\
\text { KJ.19.TA7.2.FR3, } \\
\text { KJ.19.TA7.2.FR7 }\end{array}$}} & \multirow{2}{*}{\multicolumn{2}{|c|}{$\begin{array}{l}\text { Chamber } 5 \\
\text { KJ.19.TA7.2.FR5 }\end{array}$}} & \multirow{2}{*}{\multicolumn{2}{|c|}{$\begin{array}{l}\text { Chamber } 7 \\
\text { KJ.19.TA7.2.FR6 }\end{array}$}} \\
\hline & & & & & & & & \\
\hline & NISP & MNI & NISP & MNI & NISP & MNI & NISP & MNI \\
\hline Aves & 1 (FR.1) & 1 & 1 (FR.3) & 1 & & & & \\
\hline Capra hircus & 4 (FR.4) & 1 & & & 4 & 1 & & \\
\hline $\begin{array}{l}\text { Ovis } \quad \text { vel } \\
\text { Capra }\end{array}$ & $\begin{array}{l}4 \text { (FR.1); } \\
3 \text { (FR.2); } \\
6 \text { (FR.4) }\end{array}$ & 2 & & & 5 & 1 & 3 & 1 \\
\hline Sus scrofa & $\begin{array}{l}1 \text { (FR.2) } \\
1 \text { (FR.4) }\end{array}$ & 1 & & & & & & \\
\hline Bos taurus & & 1 & 5 (FR.3) & & & & & \\
\hline Equus asinus & & & $\begin{array}{l}10 \\
\text { (FR.7) }\end{array}$ & 1 & & & & \\
\hline Equidae & $\begin{array}{l}1 \text { (FR.1), } 1 \\
\text { (FR.4) }\end{array}$ & 1 & 3 (FR.3) & 1 & & & & \\
\hline $\begin{array}{l}\text { Medium } \\
\text { mammals }\end{array}$ & $\begin{array}{ll}8 & \text { (FR.1); } \\
12 & \text { (FR.4) }\end{array}$ & & 2 (FR.3) & & 1 & & & \\
\hline $\begin{array}{l}\text { Large } \\
\text { mammals }\end{array}$ & 2 (FR.4) & & & & 4 & & & \\
\hline Indeterminate & $\begin{array}{lr}3 & \text { (FR.1); } \\
9 & \text { (FR.2); } \\
12 & \text { (FR.4) }\end{array}$ & & 3 (FR.3) & & 5 & & 5 & \\
\hline
\end{tabular}

Tab. 1 - Number of Identified Specimens (NISP) and Minimum Number of Individuals (MNI) of the faunal remains found in Tomb A7 of Khalet al-Jam'a.

\subsection{Burial $15 a+b$}

In the western half of Chamber 5, along the northern wall of the tomb (fig. 11), a burial was identified (Burial 15a+b) under a thick layer of collapsed ceiling (Filling 16, that was covered by Filling 13, see $\S 2$.). Human bones were preserved in a scattered and mixed distribution. Due to the preservation state, it was possible to recognize (tab. 2): a skull

63 Pig is not very common in IA II southern sites of the Levant, although a very small percentage has been found in IA IIB strata at Tel Moza/Qalunya and Jerusalem/al-Quds and a slightly big amount at Beer-Sheba (SapirHen - Finkelstein 2015, 311, fig. 3; Maeir - Hitchcock - Horwitz 2013, 5, fig. 2).

64 KJ.19.TA7.2.FR7. They are left and right molars and premolars in connection with each other, identifying a single individual (Barone 2003).

65 Horwitz 1996, 313; Horwitz - Tchernov 1996, 298-299; Sade 2009, 202-205; Horwitz - Lernau 2018, $292-$ 293. 
fragment, some decidual teeth, a mastoid process, ${ }^{66}$ four pelvis bones, several ribs, vertebral bodies and branches, one cervical vertebra with almost welded branches, two astragali of different size, several not-welded epiphyses. Preliminary analysis of bones, in particular of the size of the vertebrae, of the size of the two astragali and of the number of pelvis, revealed that there were two buried childhood individuals: the first one was less than 2 years old (fig. 15), ${ }^{67}$ and the second one over 6 years old (fig. 16). ${ }^{68}$

\begin{tabular}{|l|l|}
\hline Burial 15a (KJ.19.TA7.15.HR1) & Burial 15b (KJ.19.TA7.15.HR2) \\
\hline & 1 skull fragment \\
\hline \begin{tabular}{l} 
18 vertebral bodies and 6 vertebral branches \\
\hline 2 pelvis
\end{tabular} & 1 cervical vertebra with welded branches \\
\hline $\begin{array}{l}5 \text { epiphyses of long bones, of which } 2 \text { femur heads and 1 } \\
\text { distal tibia epiphysis }\end{array}$ & 2 pelvis \\
\hline 1 astragalus & 1 femur head \\
\hline 13 non-welded diaphyses of ribs & 1 astragalus \\
\hline 7 non-welded diaphyses of phalanges & 9 phalanges \\
\hline & 6 long bones fragments \\
\hline
\end{tabular}

Tab. 2 - List of human bones found in Burial 15a and Burial 15b of Tomb A7 of Khalet al-Jam'a.

The ceramic finds were laid in the eastern part of Chamber 5 and found mixed with bones. They accompanied different inhumations (figs. 12-14). Pottery vessels date back from different epochs: one EB IVB jars with combed decoration on the shoulders ${ }^{69}$ (fig. 14); one MB I Gublite carinated bowl ${ }^{70}$ (fig. 12), one Red Slip cylindrical juglet ${ }^{71}$ (fig. 13), one Black Burnished piriform juglet with button base ${ }^{72}$ (fig. 12), one Black Burnished piriform juglet with ring base ${ }^{73}$ (fig. 12), one MB III Simple Ware platter with inner folded rim $^{74}$ (fig. 12), one Simple Ware juglet ${ }^{75}$ (fig. 12, preserved at rim and neck), one Simple Ware dipper $^{76}$ (fig. 12), one MB II Storage Ware jar ${ }^{77}$ and one Iron Age II jar, apparently intrusive from the upper layer ${ }^{78}$ (fig. 14).

Then, according to the pottery repertoire, it seems to be possible that the tomb was first excavated during the Early Bronze IVB when burials $15 \mathrm{a}+\mathrm{b}$ belong to, and it remained in

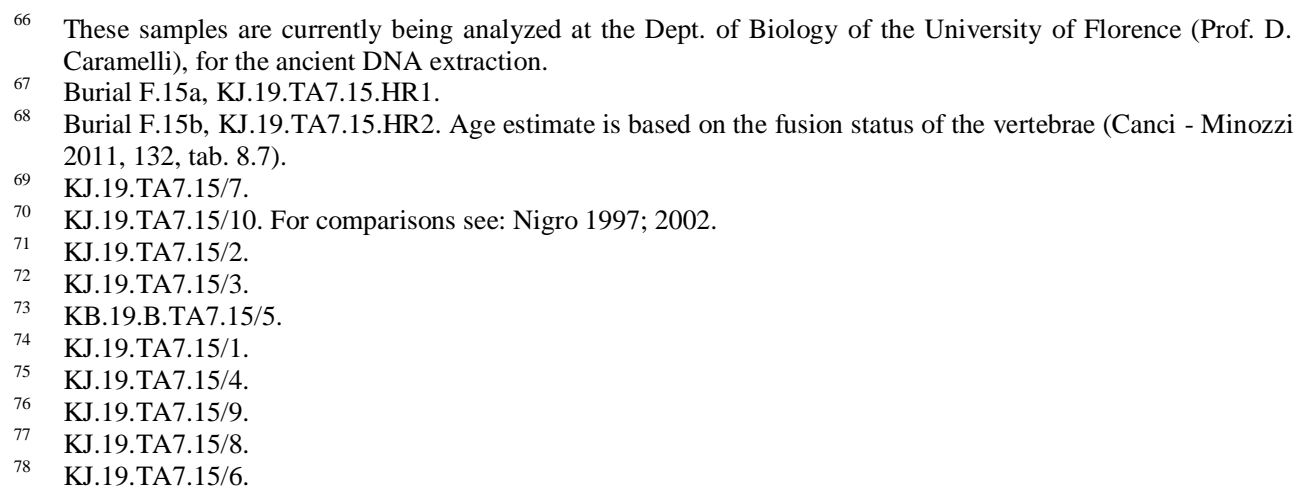


use during the whole Middle Bronze Age until the end of Middle Bronze III, similarly to what happened for other tombs of the same necropolis. ${ }^{79}$

\section{CONCLUSIONS}

Tomb A7 seems to have originally consisted of three different tombs, subsequently unified into one large underground complex during the Iron Age II. One tomb corresponded to Chambers 1, 8 and 9 with shafts 5 and 2, the second tomb to chambers 6 and 10, with Shaft 6 , and the third one to Chambers 3, 4, 5, and 7, with Shaft 7.

The third tomb should represent the oldest nucleus of the structure, hewn in the EB IVB-MB I and kept in use during the whole Middle Bronze Age, as suggested by the funerary equipment. Its entrance was probably through Shaft 7 . Afterward, in the $8-7^{\text {th }}$ centuries $\mathrm{BC}$, the three tombs were rearranged, cleaned and then joined together by means of Chamber 2 and Shaft 1. Chambers 1, 9, 8, 10 and 6 were connected, by widening rooms and straightening walls. Shafts 3 and 4 were excavated, as aeration wells or for dropping raw materials. These variation of the tomb arrangement apparently indicate a change in the use of the cave, which was transformed into an underground production and storage area, associated with the nearby Iron Age Tower. ${ }^{80}$

Pottery ( $\$ 2.1$.$) , small finds ( \$ 2.2$.), human ( $\$ 2.4$.), and faunal ( $\$ 2.5)$ remains collected in Tomb A7 provide more information about Bethlehem in Iron Age II, while the city was an administrative center related to the Jerusalem/al-Quds district, ${ }^{81}$ as already seen in the rich assemblage found in the Barmil Tomb (D13) of Khalet al-Jam'a. ${ }^{82}$

\section{REFERENCES}

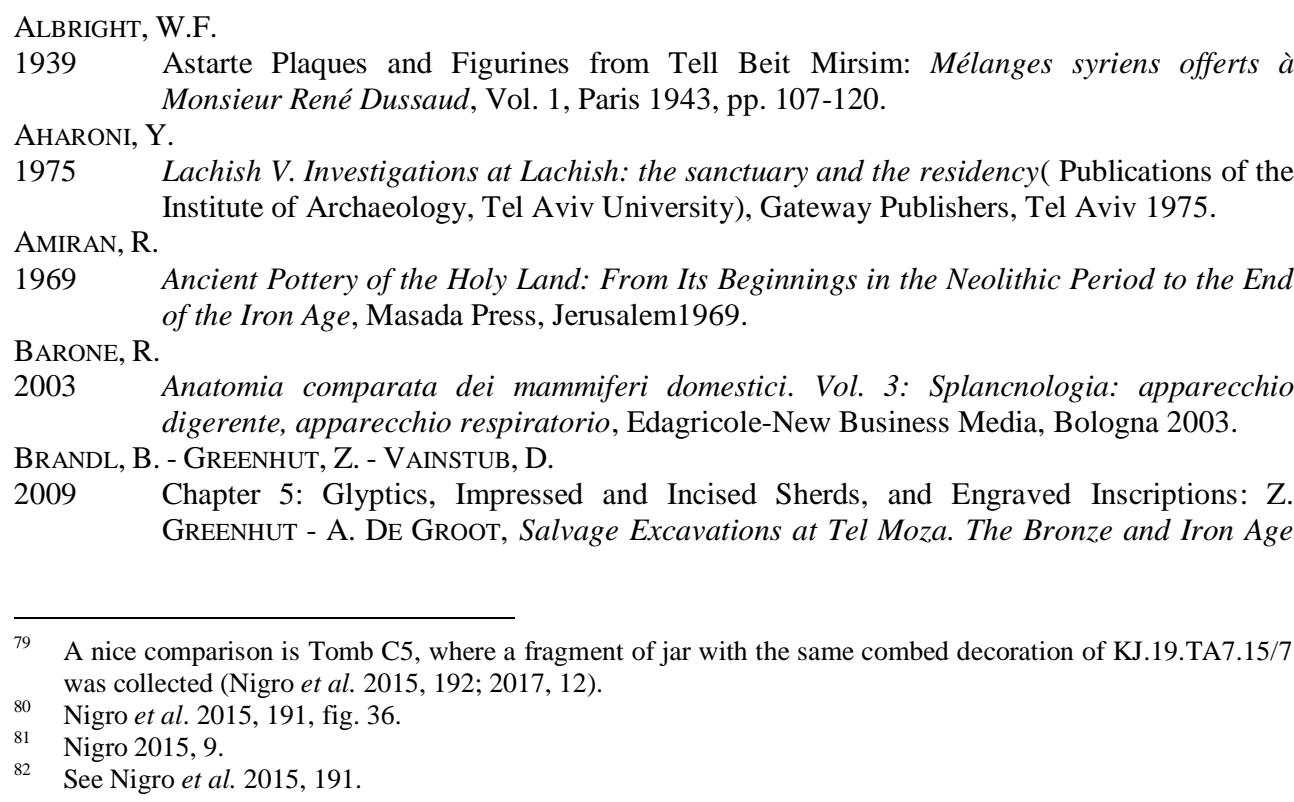


Settlement and Later Occupations (Israel Antiquities Authority Reports 39), Jerusalem 2009, pp.125-147.

CANCI, A. - MinOZZI, S.

$2011 \quad$ Archeologia dei resti umani, Carocci Editore 2011.

Crowfoot, J.W. - CROwFOOt, G.M. - KenYon, K.M.

1957 The Objects from Samaria, Palestine Exploration Fund, London 1957.

DARBY, E.

2014 Interpreting Judean Pillar Figurines: Gender and Empire in Judean Apotropaic Ritual (Forschungen zum Alten Testament 2. Reihe 69), Mohr Siebeck, Tübingen 2014.

De Groot, A. - BERNICK-GREENBERG, H.

2012 Excavations at the City of David 1978-1985 directed by Yigal Shiloh, Vol. VIIA: Area E, The Finds (Qedem 54), Jerusalem 2012.

FREUD, L.

2016 Chapter 16: Pottery of the Iron Age: Typology and Summary: O. LIPSCHITS - Y. GADOT L. Freud, Ramat Rahel III. Final Publication of Yohanan Aharoni's Excavations (1954, 1959-1962), Vol. I, Winona Lake, Eisenbrauns 2016, pp. 254-265.

GiTIN, S.

2015 Chapter 3.3. Iron Age IIC: Judah: S. GITIN (ed.), The Ancient Pottery of Israel and its Neighbhours: From Iron Age to the Hellenistic Period, Israel Exploration Society, Jerusalem 2015.

GILBERT-PERETZ, D.

1996 Chapter Two. Ceramic Figurines: D.T. Ariel - A. De Groot (eds.), Excavations at the City of David 1978-1985 directed by Yigal Shiloh, Vol. IV: Various reports (Qedem 35), Jerusalem 1996, pp. 29-41.

GreEnhut, Z. - De Groot, A.

2009 Chapter 3: The Pottery: Z. Greenhut - A. De Groot, Salvage Excavations at Tel Moza. The Bronze and Iron Age Settlement and Later Occupations (Israel Antiquities Authority HADLEY, J. M Reports 39), Jerusalem 2009, pp. 61-114.

2000 The Cult of Asherah in Ancient Israel and Judah. Evidence for a Hebrew Goddess (University of Cambridge Oriental Publications 57), Cambridge University Press, Cambridge 2000

HOLLAND, T.A.

1977 A Study of Palestinian Iron Age Baked Clay Figurines, with special reference to Jerusalem: Cave 1: Levant 9 (1977), pp. 121-155.

HORWITZ, L.K.

1996 Chapter eleven: Faunal Remains from Areas A, B, D, H and K: D. T. ARIEL - A. DE GroOT (eds.), Excavations at the City of David 1978-1985 directed by Yigal Shiloh, Vol. IV: Various reports (Qedem 35), Jerusalem 1996, pp. 302-317.

HORWITZ L.K. - LERNAU O.

2018 Iron Age IIB faunal remains from the Ophel, Area A2009: E. MAZAR (ed.) The Ophel. Excavations to the South of the Temple Mount 2009-213. Final Reports Volume II, Shoham Academic Research and Publication, Jerusalem 2018, pp. 289-309.

HORWITZ, L.K. - TCHERNOV, E.

1996 Chapter ten: Bird Remains from Areas A, B, D, H and K: D.T. ARIEL - A. De Groot (eds.), Excavations at the City of David 1978-1985 directed by Yigal Shiloh, Vol. IV: JOHNSTON, P. Various reports (Qedem 35), Jerusalem 1996, pp. 298-301.

2003 Figuring out Figurines: Tyndale Bulletin 54/2 (2003), pp. 81-104. 
KLETTER, R.

1996 The Judean Pillar-Figurines and the Archaeology of Asherah (British Archaeological Reports International Series 636), Oxford 1996.

2001 "Between Archaeology and Theology: The Pillar Figurines from Judah and the Asherah: A. MAZAR (ed.), Studies in the Archaeology of the Iron Age in Israel and Jordan (Journal for the Study of the Old Testament Supplement Series 331), pp.179-216.

2016 Chapter 21: Clay Figurines: Z. HerZOG - L. SINGER-AviTZ (eds.), Beer-Sheba III. The Early Iron IIA Enclosed Settlement and the Late Iron IIA - Iron IIB Cities (Tel Aviv University, Sonia and Marco Nadler Institute of Archaeology, Monograph Series 33), Tel Aviv 2016, pp. 1075-1136.

LAPP, N.L.

1978 The Third Campaign at Tell el-Ful: The Excavations of 1964 (Annual of the American Schools of Oriental Research 45), American Schools of Oriental Research, Cambridge 1978.

LEMAIRE, A.

1981 Classification des estampilles royales Judéennes: Eretz Israel 15 (1981), pp. 54*-59*.

LIPSCHITS, O. - SERGI, O. - KOCH, I.

2010 Royal Judahite Jar Handles: Reconsidering the Chronology of the lmlk Stamp Impressions: Tel Aviv 37 (2010), pp. 3-32.

2011 Judahite Stamped and Incised Jar Handles: A Tool for Studying the History of Late Monarchic Judah: Tel Aviv 38 (2011), pp. 5-41.

MAEIR, A.M. - HitCHCOCK, L.A. - HORWITZ, L.K.

2013 On the Constitution and Transformation of Philistine Identity: Oxford Journal of Archaeology 32/1 (2013), pp. 1-38.

MARShALl, F. - PILGRAM, T.

1993 NISP vs. MNI in Quantification of Body-Part Representation: American Antiquity 58/2 (1993), pp. 261-269.

McCown, C.C. - WAMPLER, J.C.

1947 Tell en-Nașbeh, Excavated Under the Direction of the Late Willian Frederic Badè, Vols. I-II( Palestine Institute of Pacific School of Religion - American Schools of Oriental Research), Berkeley - New Heaven 1947.

MEYERS, C.L.

2002 From Household to House of Yahweh: Women's Religious Culture in Ancient Israel: A. Lemaire (ed.), Congress Volume Basel 2001 (Vetus Testamentum, Supplements, Volume 92), Brill, Leiden 2002, pp. 277-303.

MOOREY, P.R.S.

$2001 \quad$ Idols of the People (The British Academy), Oxford 2001.

NigRO, L.

1997 Ebla and the Ceramic Provinces of Northern Syria in the Middle Bronze Age: Relationships and Interconnections with the Pottery Horizons of Upper Mesopotamia: M. LeBeAu (ed.), About Subartu. Studies devoted to Upper Mesopotamia 1: Landscape, Archaeology, Settlement (Subartu IV.1), Brepols 1997, pp. 271-304.

2002 The MB Pottery Horizon of Tell Mardikh/Ancient Ebla in a Chronological Perspective: M. BIETAK (ed.), The Middle Bronze Age in the Levant, Proceedings of an International Conference on MBIIA Ceramic Material, Vienna, 24th-26th of January 2001 (Contributions to the Chronology of the Eastern Mediterranean Volume III), Wien 2002, pp. 297-328.

2015 Bethlehem in the Bronze and Iron Ages in the light of recent discoveries by the Palestinian MOTA-DACH: Vicino Oriente XIX (2015), pp. 1-24. 
Nigro, L.- MonTANARi, D.- GHAyYADA, M.- YASINE, J.

2015 Khalet al-Jam'a. A Middle Bronze and Iron Age Necropolis near Bethlehem (Palestine) Vicino Oriente XIX (2015), pp. 183-214.

Nigro, L. - Montanari, D. - Guari, A. - Tamburrini, M. - Izzo, P. - Ghayyada, M. - Titi, I. YASSINE, J.

2017 New archaeological features in Bethlehem (Palestine): The Italian-Palestinian Rescue Season of November 2016: Vicino Oriente XXI (2017), pp. 5-57.

Nigro, L.- SALA, M. - TAHA, H. - Yassine, J.

2011 The Early Bronze Age Palace and Fortifications at Tell es-Sultan/Jericho. The $6^{\text {th }}-7^{\text {th }}$ seasons (2010-2011) by Rome "La Sapienza" University and the Palestinian MOTA-DACH: Scienze dell'Antichità 17 (2011), pp. 731-744.

'O CONNOR, $\mathrm{T}$.

2004 The Archaeology of Animal Bones, Sutton Publishing, Sparkford 2004.

Petersson-Solimany, M. - Kletter, R.

2009 Chapter 4: The Iron Age Clay Figurines and a Possible Scale Weight: Z. GreENHUT - A. De Groot, Salvage Excavations at Tel Moza. The Bronze and Iron Age Settlement and Later Occupations (Israel Antiquities Authority Reports 39), Jerusalem 2009, pp. 115123.

PRAG, K

2001 Figurines, Figures and Contexts in Jerusalem and Regions to the East in the Seventh and Sixth Centuries BCE: A. MAZAR (ed.), Studies in the Archaeology of the Iron Age in Israel and Jordan (Journal for the Study of the Old Testament Supplement Series 331), Sheffield Academic Press, Sheffield 2001, pp. 217-234.

PRITCHARD, J.B

1959 Hebrew inscriptions and stamps from Gibeon (Museum monographs, The University Museum, University of Pennsylvania), Philadelphia 1959.

RICE, P.

1987 Pottery Analysis: A Sourcebook, University of Chicago Press, Chicago1987.

SADE, $M$.

2009 Chapter 10: The Archeozoological Remains: Z. GreEnhut - A. De Groot, Salvage Excavations at Tel Moza. The Bronze and Iron Age Settlement and Later Occupations (Israel Antiquities Authority Reports 39), Jerusalem 2009, pp. 199-207.

SAPIR-HEN, L. - FINKELSTEIN, I.

2015 Iron Age Pigs: New Evidence on Their Origin and Role in Forming Identity Boundaries: Radiocarbon 57.2 (April 2015), pp. 307-315.

SEEVERS, B

2016 A Headless Judean Pillar Figurine from Tell el-Ful: Near East Archaeological Society Bulletin 61 (2016), pp. 37-43.

SERGI, O.

2016 Chapter 19: Lmlk Stamp Impressions: O. LIPSCHITS - Y. GADOT - L. FrEUD, Ramat Rahel III. Final Publication of Yohanan Aharoni's Excavations (1954, 1959-1962), Vol. II, Winona Lake, Eisenbrauns 2016, pp. 287-343.

SERGI, O. - KOCH, I.

2016 Chapter 21: Concentric Circle Incisions: O. LiPSChITS - Y. GAdOT - L. Freud, Ramat Rahel III. Final Publication of Yohanan Aharoni's Excavations (1954, 1959-1962), Vol. II, Winona Lake, Eisenbrauns 2016, pp. 356-367.

SINGER-AVITZ, L.

2016 Chapter 12: Pottery from Strata III-I: The Iron IIB Period: Z. HeRZOG - L. SingER-AvITZ (eds.), Beer-Sheba III. The Early Iron IIA Enclosed Settlement and the Late Iron IIA - 
Iron IIB Cities (Tel Aviv University, Sonia and Marco Nadler Institute of Archaeology, SPARKS, R.T. Monograph Series 33), Tel Aviv 2016, pp. 583-991.

2007 Stone Vessels in the Levant (The Palestine Exploration Fund Annual 8), Leeds, Maney Publishing 2007.

SQUITIERI, A.

2015 Basalt Vessel Distribution in the Southern Levant during the Iron Age: G. AfFANNI - C. BACCARin - L. Corder - A. Di Michele - K. Gavagnin (eds.), Broadening Horizons 4. A Conference of young researchers working in the Ancient Near East, Egypt and Central Asia, University of Torino, October 2011 (British Archaeological Report International Series 2698), Oxford 2015, pp. 209-215.

TUFNELL, O.

$1953 \quad$ Lachish III (Tell ed Duweir). The Iron Age, New York 1953.

Voss, B. - ALLEN, R.

2010 Guide to Ceramic MNV Calculation Qualitative and Quantitative Analysis: Technical WRIGHT, K. Briefs in historical archaeology 5 (2010), pp. 1-9.

1992 A Classification System for Ground Stone Tools from the Prehistoric Levant: Paléorient 18.2 (1992), pp. 53-81.

YEZERSKI, I. - GEVA, H.

2003 Chapter three: Iron Age II Clay Figurines: H. GEVA (ed.), Jewish Quarter Excavations in the Old City of Jerusalem, Conducted by Nahman Avigad, 1969-1982, II, Jerusalem, pp. 63-84.

ZIMHONI, O.

2004 The Pottery of Levels III and II: D. UsSishrin (ed.), The Renewed Archaeological Excavations at Lachish 1973-1994, Tel Aviv, pp. 1789-1899. 


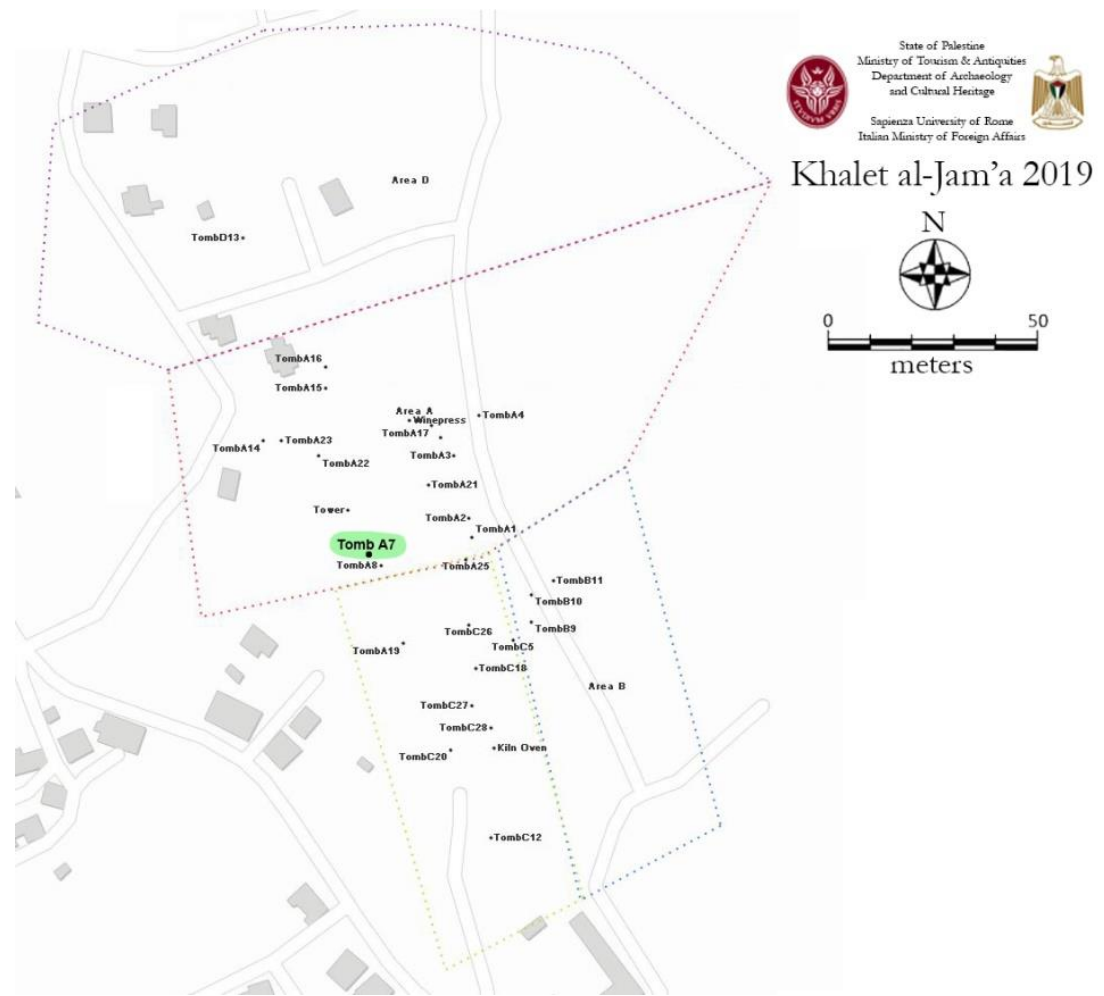

Fig. 1 - Map of the Necropolis of Khalet al-Jam'a (lasapienzatojericho.it/Betlemme/MAP).

Fig. 2 - Shaft 1 of Tomb A7 of the Necropolis of Khalet al-Jam'a, from south.

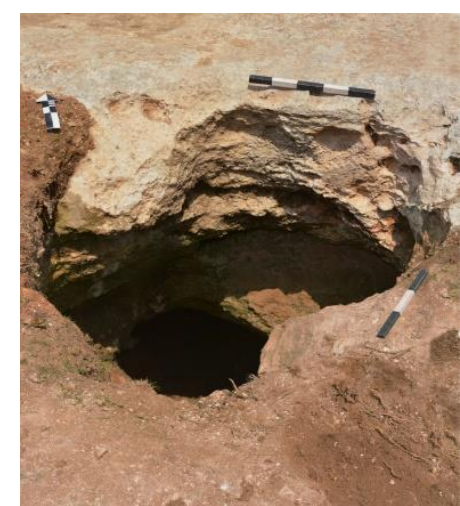




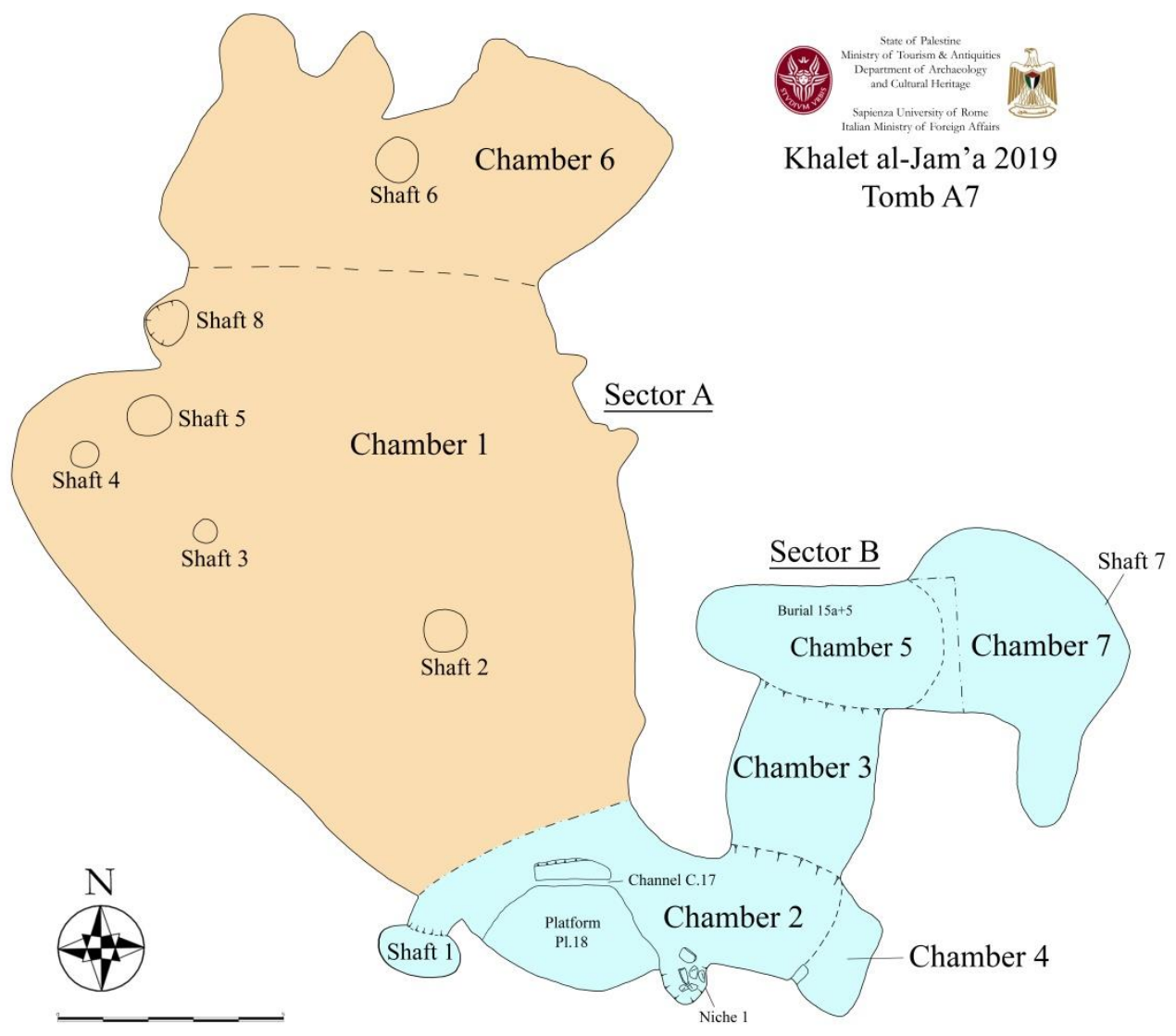

Fig. 3 - Plan of Tomb A7 of the Necropolis of Khalet al-Jam'a. 


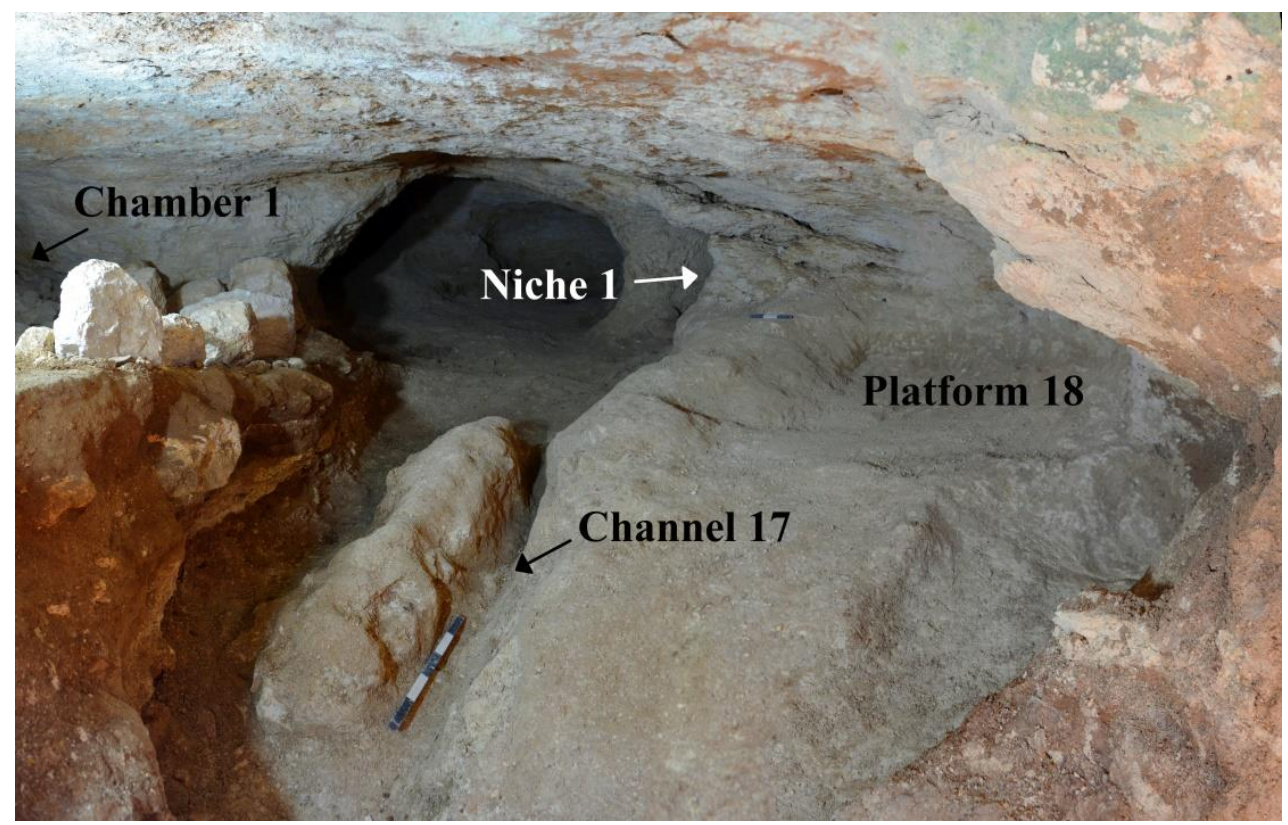

Fig. 4 - Chamber 2 of Tomb A7 of the Necropolis of Khalet al-Jam'a, view from Shaft 1.

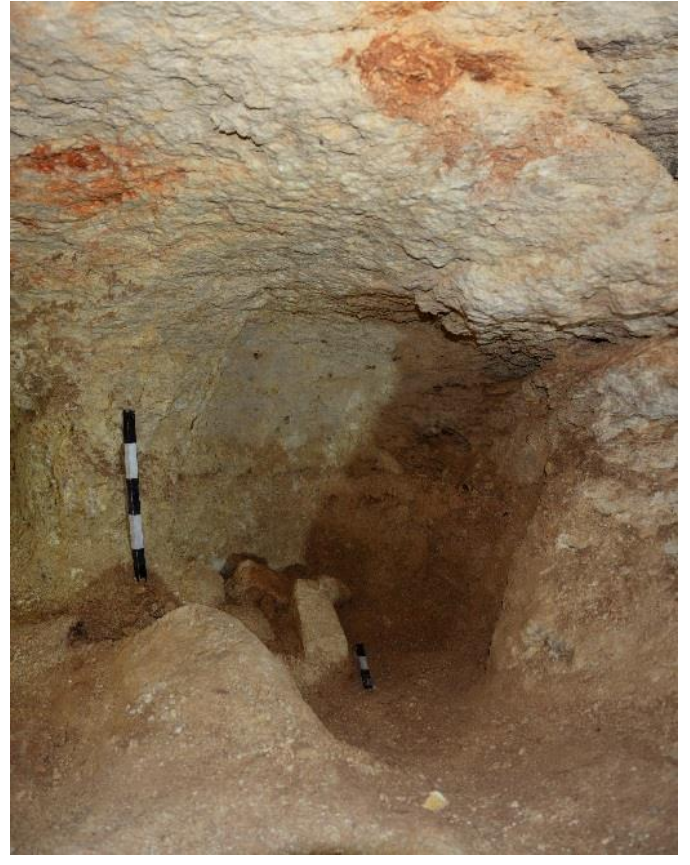

Figure 5 - Niche 1, carved inside the southern wall of Chamber 2 of Tomb A7 of the Necropolis of Khalet al-Jam'a. 

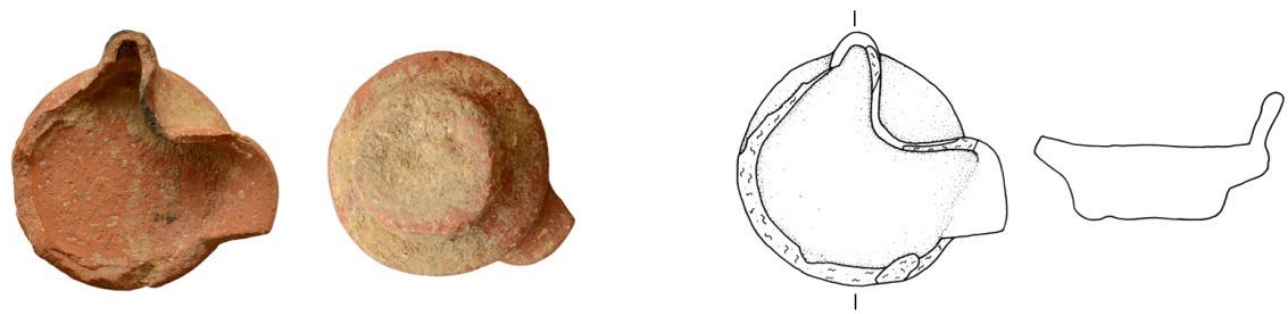

KJ.19.TA7.10/1
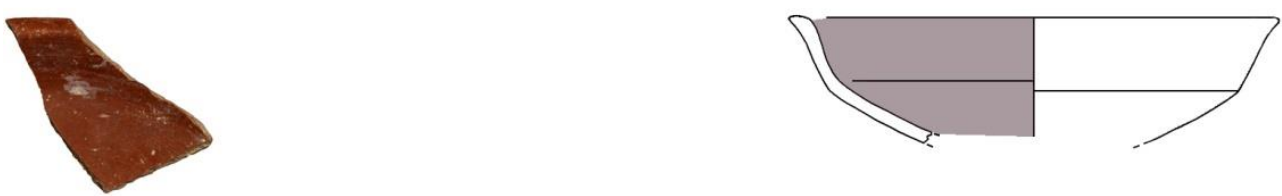

KJ.19.TA7.11/10
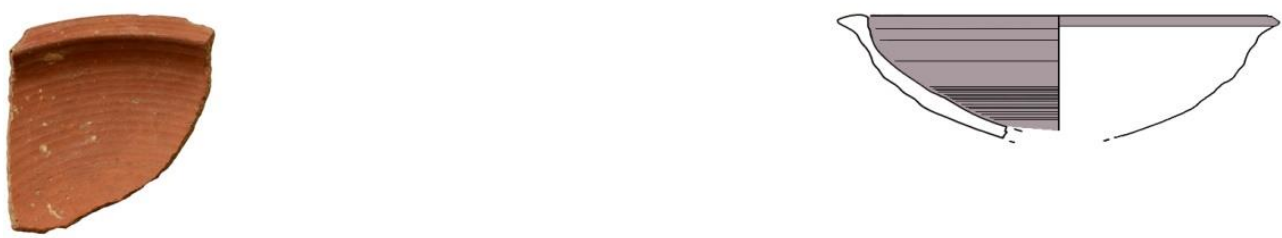

KJ.19.TA7.8/11
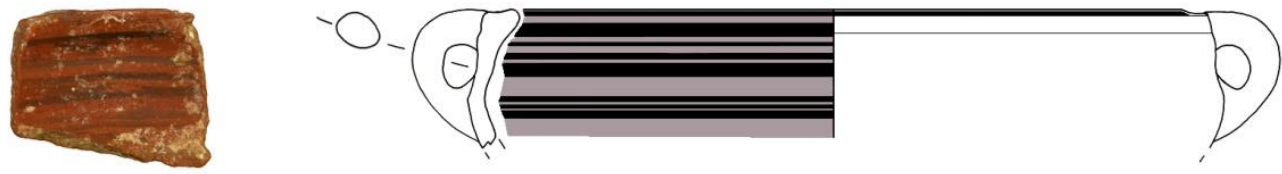

KJ.19.TA7.7/9

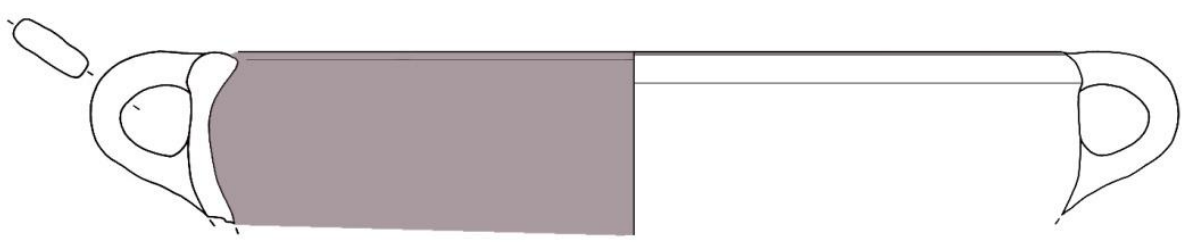

KJ.19.TA7.3/43

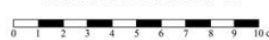

Fig. 6 - Selection of pottery from Tomb A7 of the Necropolis of Khalet al-Jam'a. 


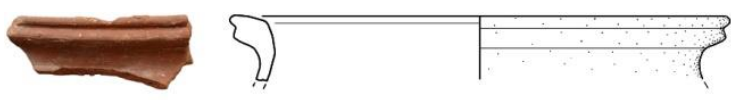

KJ.19.TA7.4/15

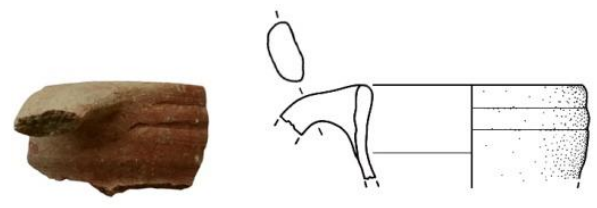

KJ.19.TA7.11/64
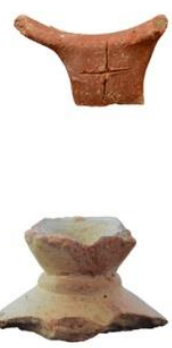

KJ.19.TA7.11/155

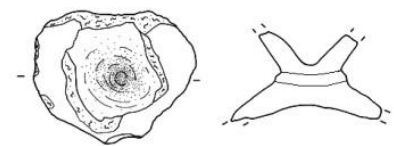

KJ.19.TA7.10/138
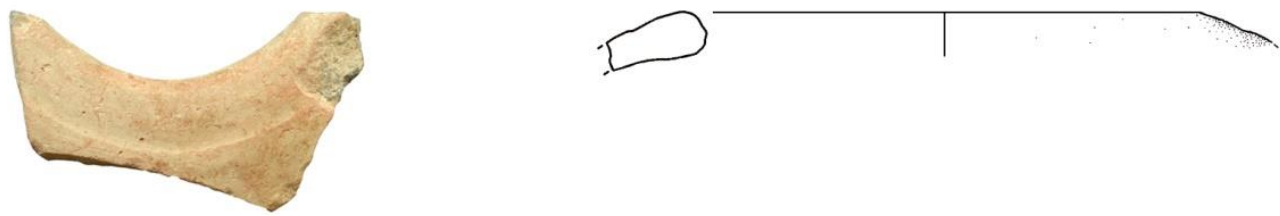

KJ.19.TA7.8/55

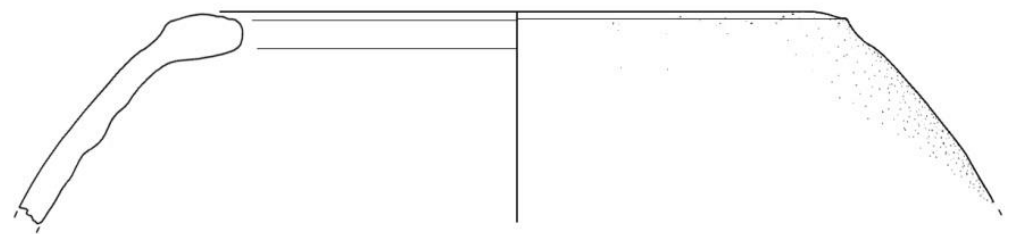

KJ.19.TA7.11/118

Fig. 7 - Selection of pottery from Tomb A7 of the Necropolis of Khalet al-Jam'a. 

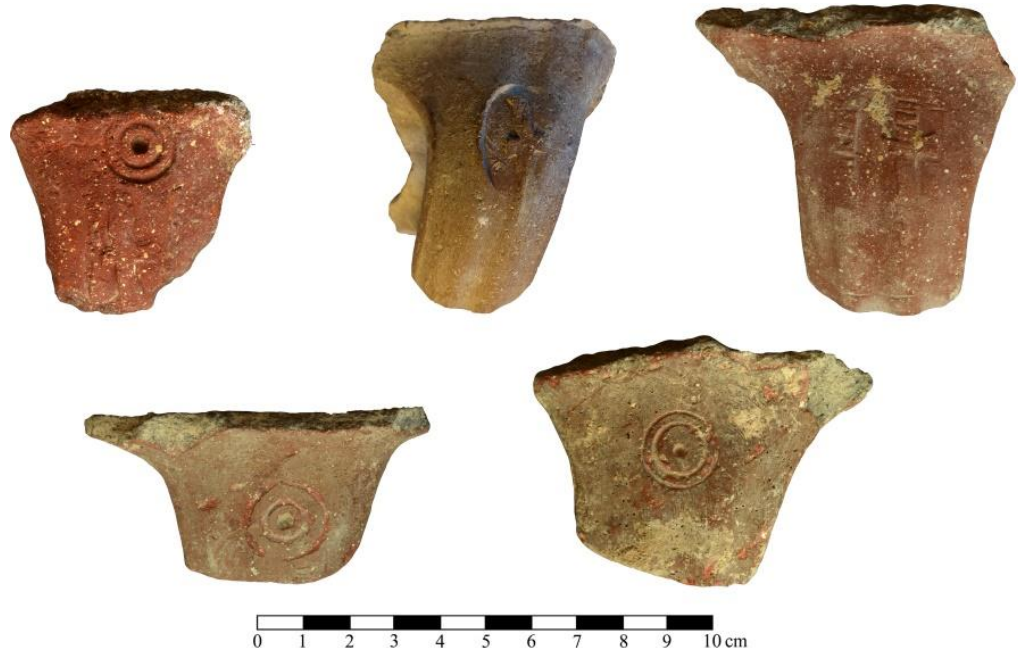

Fig. 8 - Upper line, from left to right: KJ.19.TA7.8/42 with 2-wingled lmlk stamp impression (0 II Type) and concentric circles; at the center, handle KJ.19.TA7.10/137 with 2-wingled lmlk stamp impression (X II Type), handle KJ.19.TA7.11/103, with 2-wingled lmlk stamp impression (0 II Type); lower line, from left to right: KJ.19.TA7.11/101 and KJ.19.TA7.11/102 with Concentric Circles Type stamp impression.

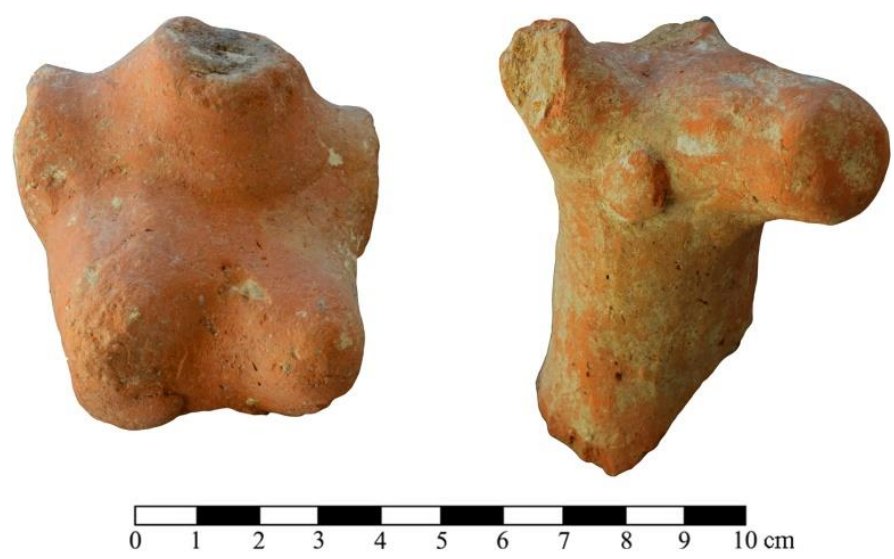

Fig. 9 - Torso of female Pillared Figurine, KJ.19.TA7.10 (left); head of equid figurine with applied eyes, KJ.19.TA7.20 (right). 
Fig. 10 - Three marābit faras found in Chamber 2 of Tomb A7: KJ.19.TA7.6 (above, left); KJ.19.TA7.5 (above, right); KJ.19.TA7.7 (down).
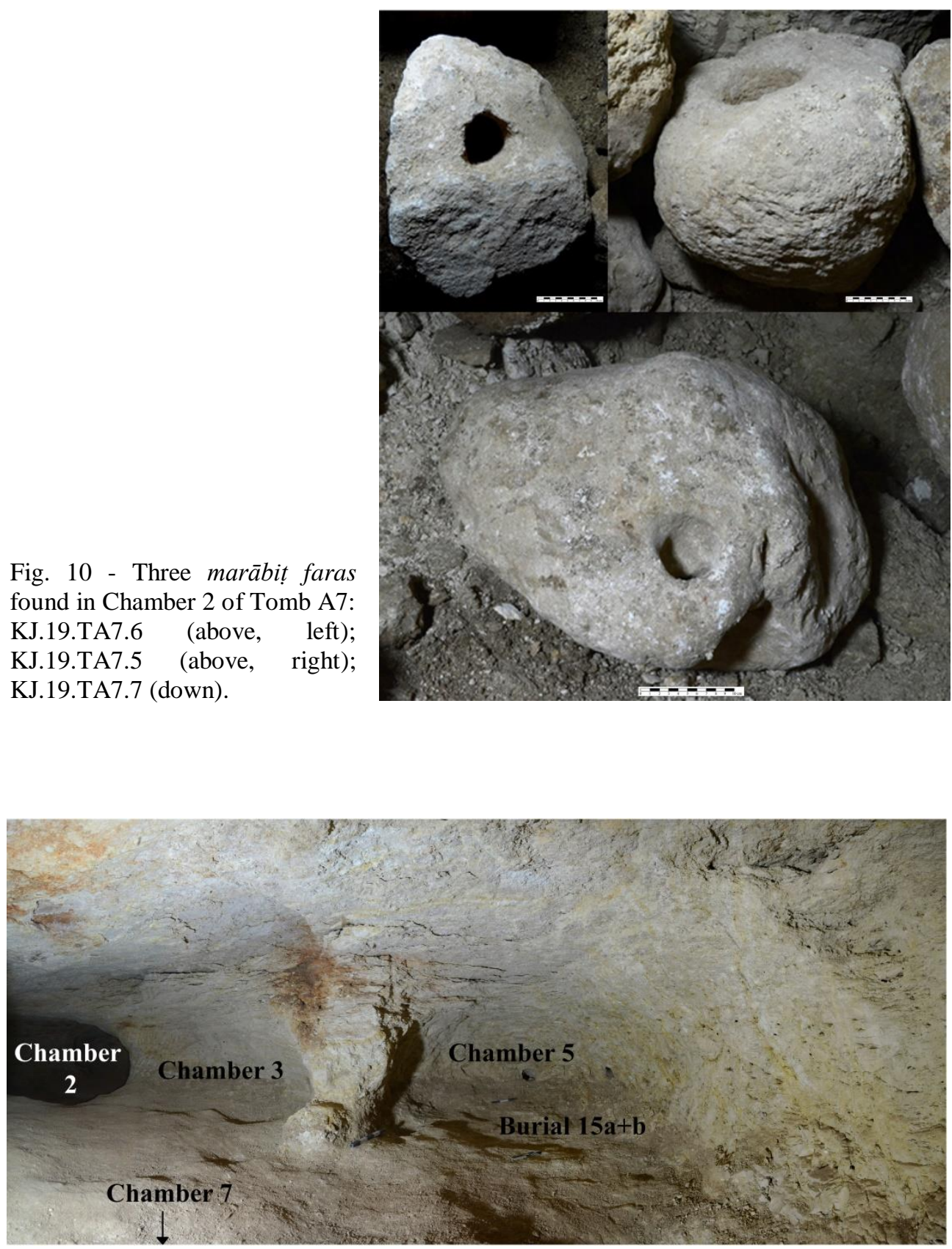

Fig. 11 - Chambers 2, 3, 5 and Burial 15a+b view from Chamber 7. 

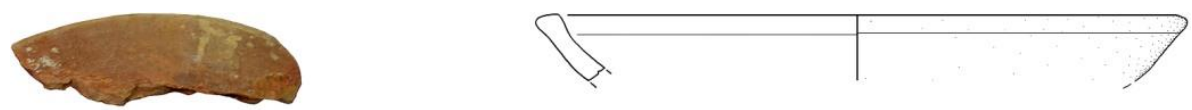

KJ.19.TA7.15/1
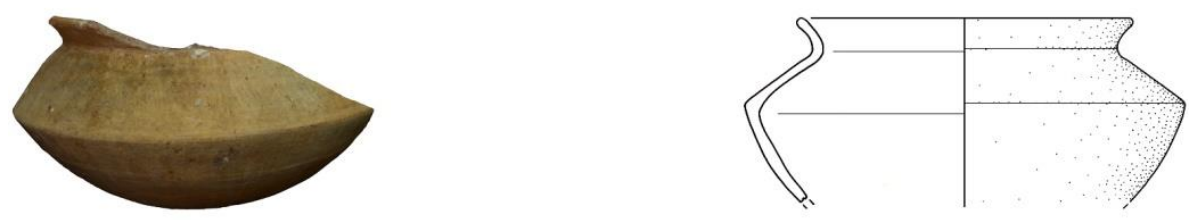

KJ.19.TA7.15/10
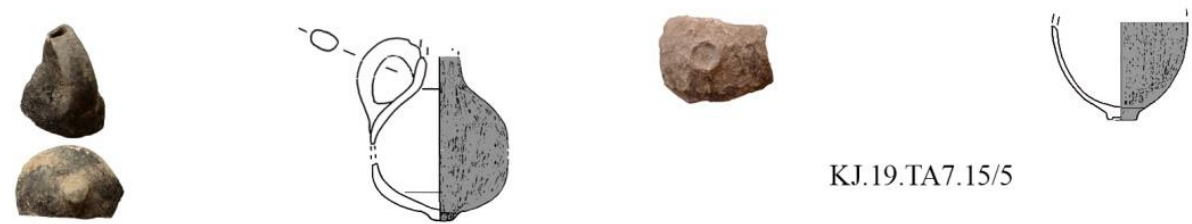

KJ.19.TA7.15/5

KJ.19.TA7.15/3
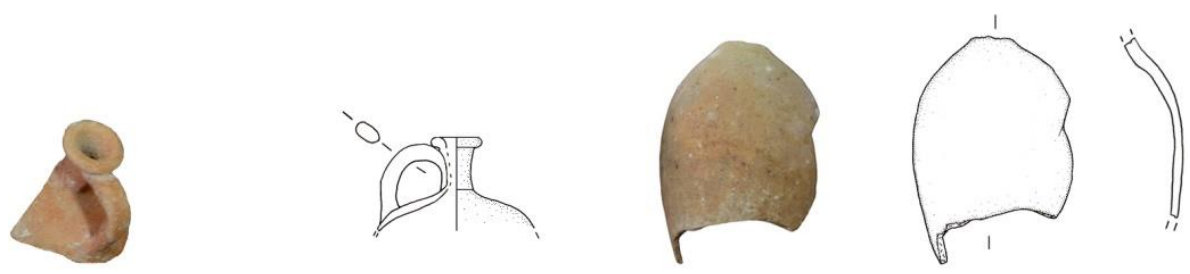

KJ.19.TA7.15/4

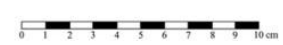

KJ.19.TA7.15/9

Fig. 12 - Pottery funerary equipment of Burial 15a+b of Tomb A7.

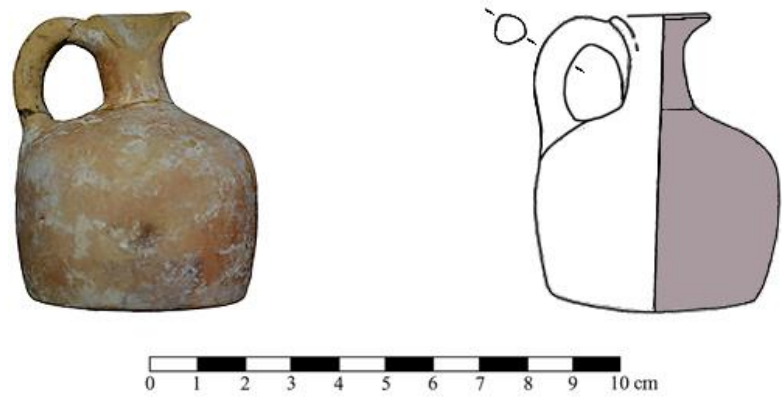

Fig. 13 - Red Slip cylindrical juglet KJ.19.TA7.15/2 found in Burial $15 \mathrm{a}+\mathrm{b}$ of Tomb A7. 

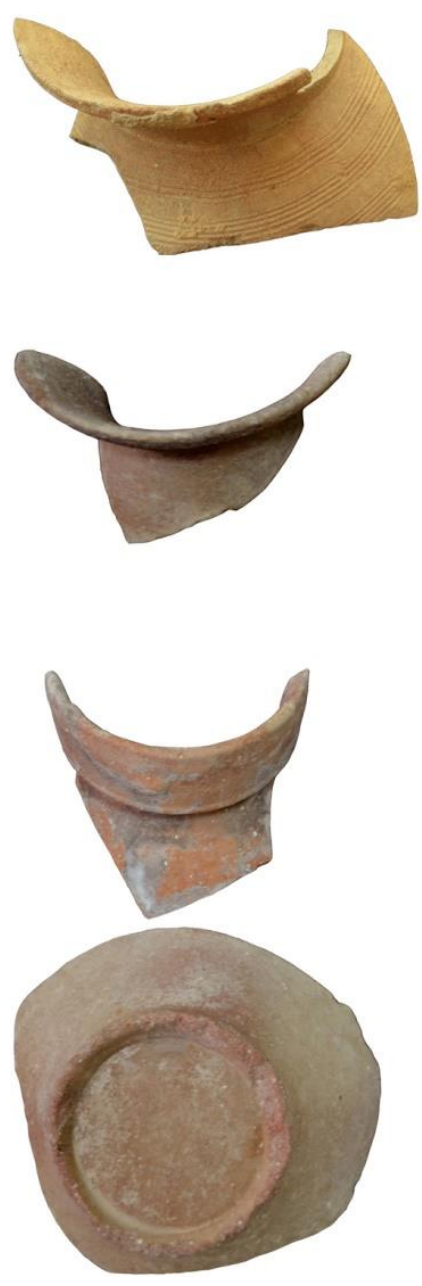

Fig. 14 - Pottery funerary equipment of Burial 15a+b of Tomb A7.

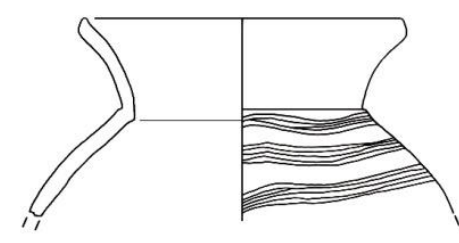

KJ.19.TA7.15/7

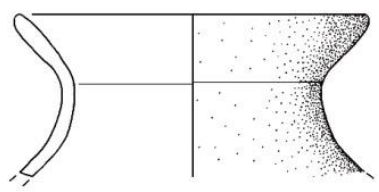

KJ.19.TA7.15/8

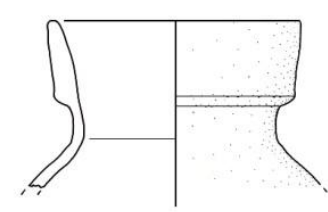

KJ.19.TA7.15/6

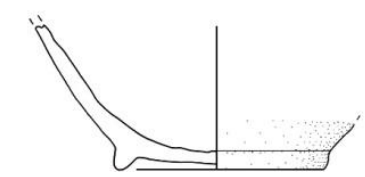




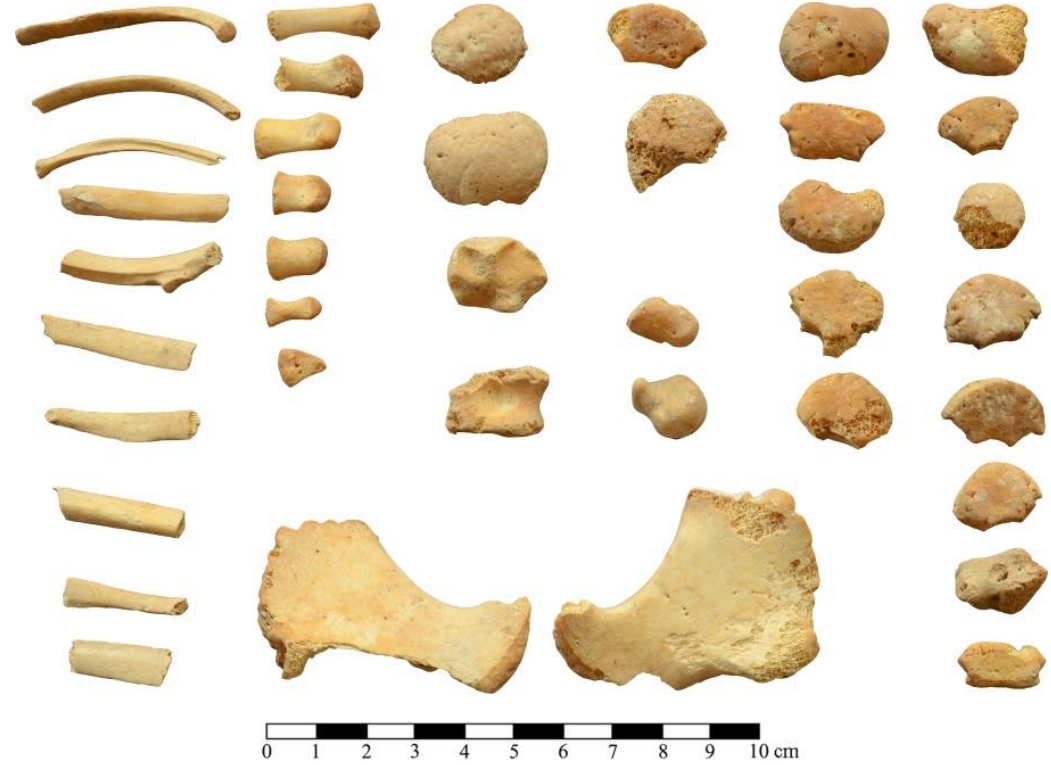

Fig. 15 - Human bones of Burial 15a (KJ.19.TA7.HR1) of Tomb A7 of the Necropolis of Khalet al-Jam'a.

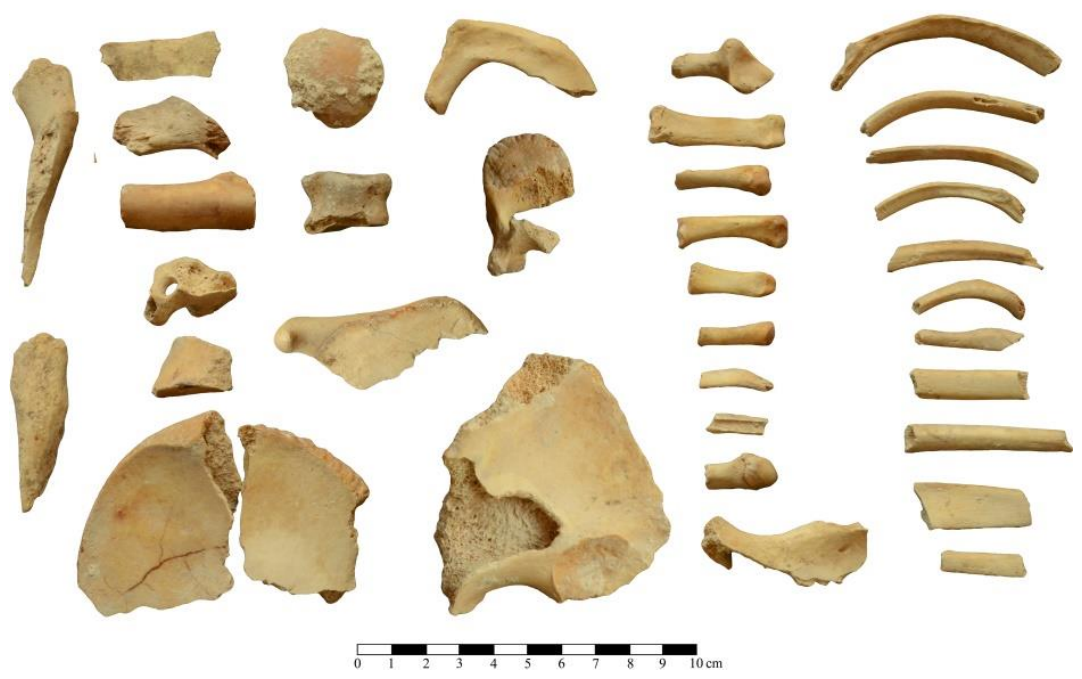

Fig. 16 - Human bones of Burial 15b (KJ.19.TA7.15.HR2) of Tomb A7 of the Necropolis of Khalet al-Jam'a. 